\title{
EFFECT OF IRRIGATION INTERVALS, BIOTIC AND ABIOTIC TREATMENTS ON WATER USE EFFICIENCY AND POTATOS YIELD IN SULAIMANI - IRAQI KURDISTAN REGION
}

\author{
KARIM, L. G. ${ }^{{ }^{*}}-$ MAHOOD, N. A. $^{2}-$ AllawI, M. M. ${ }^{3}$ \\ ${ }^{1}$ Horticulture Department, College of Agricultural Sciences, University of Sulaimani \\ Sulaimani-Kurdistan Region, Iraq \\ ${ }^{2}$ Protected Agricultural Department, Bakrajo Technical Agriculture Institute, Sulaimani, Iraq \\ ${ }^{3}$ Horticulture Department, College of Sciences Agricultural Engineering \\ University of Baghdad, Iraq \\ *Corresponding author \\ e-mail: luqman.karim@univsul.edu.iq; phone:+96-477-0143-4161
}

(Received $10^{\text {th }}$ Apr 2019; accepted $19^{\text {th }}$ Jun 2019)

\begin{abstract}
This study was carried out in two growing spring seasons 2017 and 2018 at Kanipanka

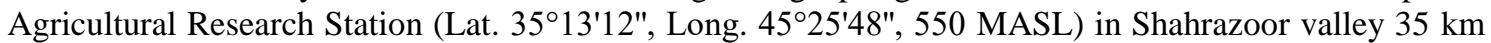
east of Sulaimani - Iraqi Kurdistan Region to investigate the effect of two irrigation intervals (5 and 10 days) and thirteen different biotic and abiotic treatments on potatoes yield water use efficiency under the field condition. The results showed that the cumulative depth of irrigation in 2017 and 2018 for 5 and 10 days were 369,228 and $363,287 \mathrm{~mm}$, respectively, while for both depth of irrigation and precipitation were 535, 394 and 513,437 mm, respectively. The effect of irrigation intervals on the WUE, IWUE and total yield (tons hectare ${ }^{-1}$ ) was significant at 2017 and 2018 season and the average of both seasons, with exception of WUE in the first season. The 5 days irrigation intervals gave the highest values for the second season and the average of both seasons for the character WUE, while 10 days irrigation intervals gave the highest values in both seasons and their average. Regarding the first season and the average of both seasons, the mycorrhizal inoculation treatments gave the highest values of WUE, IWUE and total yield but at the second season, the $\mathrm{KCl}$ with Glycyrrhiza glabra $\left(6 \mathrm{~g} \mathrm{~L}^{-1}\right)$ extract treatments gave the highest values for WUE, IWUE and total yield.
\end{abstract}

Keywords: Solanum tuberosum, water management, mycorrhizae, $\mathrm{KCl}$ application, licorice extract

\section{Introduction}

Potato (Solanum tuberosum), which belong Solanaceae family, is the fourth most agronomical important feed crops worldwide after winter wheat, maize, and rice. It is a global crop that is well-adapted wider range of altitude, latitude, and climatic conditions. Potato is a productive and exhaustive crop at the same time, requiring a variety of balanced plant nutrients for growth and development. The total world production of potatoes was 388 million tons in 2017 from this China have $25 \%$ of total production around the world with 99 million tons followed by India, Russia, Ukraine, and the United States with 48, 29, 22 and 20 million tons, respectively (FAOSTAT, 2019). Over two-thirds of the global potato production is consumed directly by humans, and the rest is used as animal feeds and starch production (FAOSTAT, 2019). The licorice roots (Glycyrrhiza glabra) extracted contain some compounds, which have similar effect to the growth promoters, and also have a wide range of minerals (phosphorus, potassium, zinc, magnesium, iron, calcium), amino acids (alanine, lysine, arginine), vitamins $\left(\mathrm{B}_{1}, \mathrm{~B}_{2}, \mathrm{~B}_{6}\right)$, with carbohydrate and nitrogen. In addition, it also 
contains mevalonic acid that can be used in gibberellins synthesis (Sarby et al., 2009). Potassium (K) foliar application is another factor that has been used for improved nutrient management and increasing potato growth and yield (Grewal et al., 1992). Generally, Potassium is one of the vital elements that affect most of the biochemical and physiological processes. The physiological and molecular mechanisms of $\mathrm{K}$ function in plant stress resistance are studied by (Wang et al., 2013). These researchers also demonstrated that adequate $\mathrm{K}$ nutritional status in the plants living under drought conditions has significant effect on root growth, leaf area, and increased cell membrane stability with total dry mass. In addition, role of potassium may facilitate osmotic adjustment, which is improved uptake of water via roots and minimize water loss during drought periods (regulates transpiratory water), consequently improving the ability of plants to tolerate drought stress (Egilla et al., 2005). Furthermore, it has also a critical role for justifying ROS (reactive oxygen species) damage as induced by drought stress because ROS are significantly accumulated under a biotic stress conditions, which cause oxidative damage and eventually resulting in cell death (Wang et al., 2013).

Microorganisms are vital component of the agricultural system. Arbuscular mycorrhizal (AM) fungi, a global soil microbe, can subordinate with the roots of most terrestrial crop species (Duc, 2017). Several benefits were observed when AM is colonized crops including; increased growth and yield, enhanced plant resistance to environmental adversities, improve plant tolerance to a biotic stress (Birhane et al., 2012) Recently, researcher confirmed that improve stress tolerance of the host plants can be done by several AM-induced mechanisms of host tolerance to a biotic stresses, such as more effective anti-oxidative systems, defense enzymes; modifications in host physiology, e.g. osmotic adjustment, gas exchange, photosynthesis; remarkable alterations of sugars, proline, polyamines, stress phytohormones, expression patterns of stress-responsive genes (Latef and Miransari, 2014). AMF can produce glycoprotein glomalin, which is act similar a glue, binding carbon, nitrogen and other biological components of soil to the mineral components, clay and sand, that has an important role for increased soil organic matter, and consequently collected highly water stability (Duc, 2017). In addition, under drought condition, direct water uptake from soil into the host plant can improved by interlacing external hyphae of mycorrhizae, thus, it is believed that has resistance to drought condition by many mechanisms including; osmotic adjustment and altering display of stomatal conductance (Wu et al., 2006).

Shock et al. (1992) studied that potato could be tolerating water deficit before tuber set without reduction in tuber quality under some water stress conditions. Potato may be quite sensitive to drought (Van Loon, 1981) as it needs frequently irrigations for suitable growth and optimum yield (Yuan et al., 2003; Kiziloglu et al., 2006). Hassan et al. (2002) found that the Stalinization and Tuberization stages were more sensitive than bulking and tuber enlargement stages. Thornton (2002) and Shock (2004) found that all growing stages of potato, especially tuber formation stage, are very sensitive to water deficit stress.

Irrigation scheduling is a means of supplying water according to crop needs. It is the process of determining when to irrigate and how much water to apply, as for factors which influencing irrigation scheduling which are soil characteristics, climatic factors, crop characters and management factors that are to be supposed in determining irrigation schedules (Reddy, 2007). Beder (2010) proposed that to appropriate irrigation scheduling can, it be conserved and maintained that avoid plant water stress. 
To achieve this objective specific and fine data of soil, plant and climatic parameters could be gathered and analyzed at specific field conditions. Ati et al. (2010) found that the water consumption of potato were $441 \mathrm{~mm}, 429 \mathrm{~mm}$ for the agricultural season 2008 and 2009, respectively. Results showed by Ati and Nafaou (2012) indicated that highest potato production was achieved when the treatment depletion $50 \%$ of available water $\left(30.26\right.$ ton $\mathrm{ha}^{-1}$ ) compared to the treatment depletion $75 \%$ of available water (25.66 ton $\mathrm{ha}^{-1}$ ). Ati et al. (2013) study the effect of different irrigation treatment (deficit irrigation) and potassium humate fertilizer on yield, the content of nitrogen, potassium, and phosphor in tuber of potato and water use efficiency in the Abu-Ghraib Region, Iraq. Potato was grown under drip irrigation with three treatments: irrigation applied when evaporation $75 \%, 100 \%$ and $125 \%$ from pan $\mathrm{A}$, and three potassium humate fertilizers: $0,1.2$ and $2.4 \mathrm{~kg} \mathrm{ha}^{-1}$ with three times additions. The seasonal potato evapotranspiration ranged from $267 \mathrm{~mm}$ to $372 \mathrm{~mm}$. The drip irrigation treatments significantly affected tuber yield of potato and recorded $29.530,27.630$ and $24.880 \mathrm{~kg}$ $\mathrm{ha}^{-1}$ for $125 \%, 100 \%$ and $75 \%$ from pan A evapotranspiration, respectively. Humus fertilizers addition has the lowest value of ETa $309 \mathrm{~mm}$ and maximum value of yield $29300 \mathrm{~kg} \mathrm{ha}^{-1}$.

Water use efficiency (WUE) defined as the tuber yield obtained per unit of water consumed as ETa or water used in cubic meter by the potato (Doorenbos and Pruitt, 1977). Rashidi and Gholami (2008) illustrated that WUE of potato in Iran ranged from 1.92 to $5.25 \mathrm{~kg} \mathrm{~m}^{-3}$. They added that few numbers of irrigation could reduce compactness of the soil. Nagaz et al. (2007) found that WUE varied around $8-14 \mathrm{~kg} \mathrm{~m}^{-}$ 3 for planted potato. Wright and Stark (1990) reported that the WUE for maximum yield range from approximately 0.05 to $0.1 \mathrm{~kg} \mathrm{ha} \mathrm{m}^{-3}$. Kirda (2002) stated that the main objective of deficit irrigation is to increase the WUE of a crop by eliminating irrigation that have little impact on yield. The objective of this study was to determine the effects of irrigation intervals and different treatments biotechnologies on yield of potato (Actrice variety) and water use efficiency in Iraq -Kurdistan region.

\section{Material and Method}

This study carried out in two spring growing seasons in 2017 and 2018 at Kanipanka

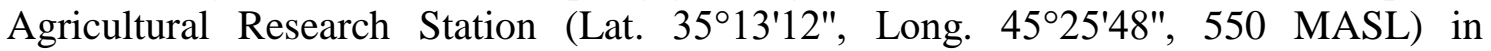
Shahrazoor valley $35 \mathrm{~km}$ east of Sulaimani - Iraqi Kurdistan Region. GIS software was used to create the study sites shown in Fig. 1. Generally, elevation of this region ranges between 5-2368 $\mathrm{m}$ above sea levels. The climate of study area is generally characterised by worm, dry summer and cold winters (Najmaddin et al., 2017).The meteorological data of Kanipanka during both growing seasons is shown in Table 1 as well as some physical and chemical properties of Kanipanka soil shown in Table 2.

\section{Bio Inoculation}

The fungal inoculants Glomus mosseae was obtained from Al-Zaefaraniya Agricultural Research Station - Ministry of Science and Technology - Baghdad. The inoculants were consisting of mycorrhizal spore with 47 spore $\mathrm{g}^{-1}$ dry soil and the residual of the infected roots. Potato tubers were inoculated with the mycorrhizal spores by using $20 \mathrm{~g}$ from the mixture of the inoculums and the pet moss inside the pores which specified for inoculation treatment before planting the tubers where the pad method was used to ensure the infection by touching the inoculums during planting. 


\section{Preparation of Glycyrriza glabra Extraction}

Three and Six gram of Glycyrriza glabra roots powder was soaked separately in one litter hot distilled water at $50^{\circ} \mathrm{C}$ for 24 hours in dark colure bottles with shaking continuously, then the solution filtered through several layers of Tapestry cloth, to obtained two concentrations of the extraction 3 and $6 \mathrm{~g} \mathrm{~L}^{-1}$ and several drop of Twin20 were added as a spread materials to reduce the surface tension. The plants were sprayed two times 45 and 60 days after planting date, after the sun seat in both years 2017 and 2018 (Lazim and Sulaiman, 2012).

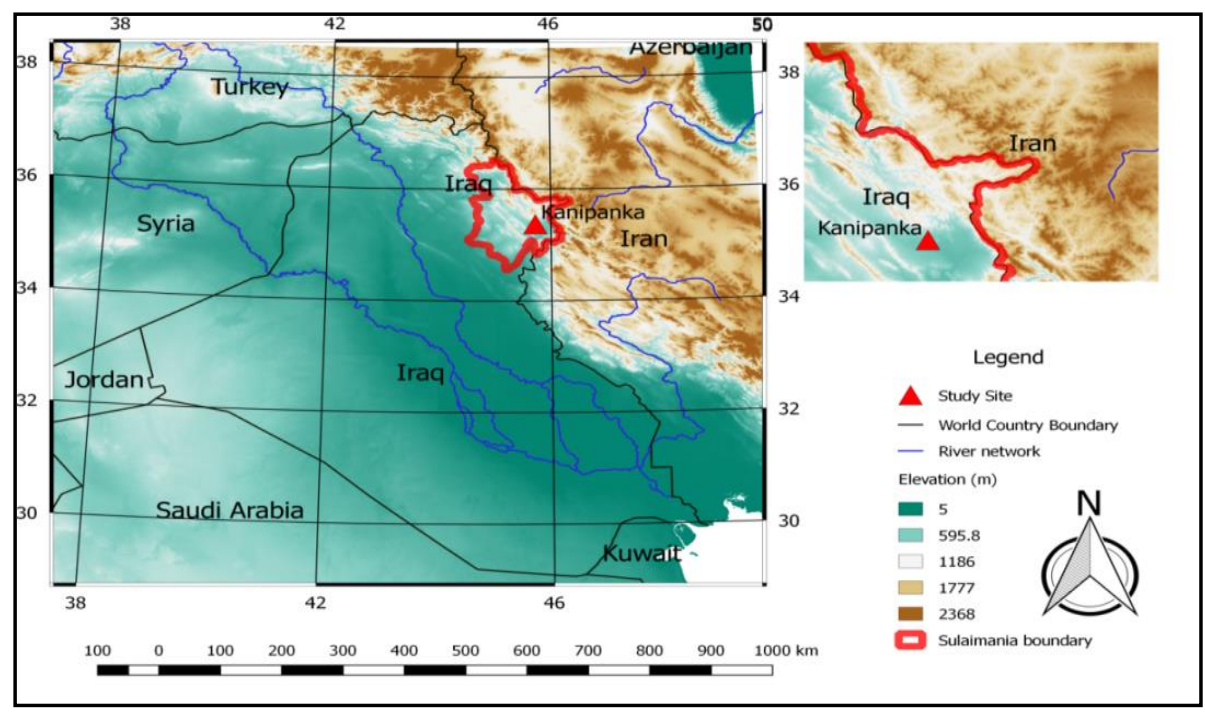

Figure 1. Regional and local location of the study site

Table 1. Meteorological data of Kanipanka location during both growing seasons (2017 and 2018)

\begin{tabular}{|c|c|c|c|c|c|c|c|c|c|}
\hline \multirow{2}{*}{ Months } & \multicolumn{3}{|c|}{ Air Temp. $\left({ }^{\circ} \mathrm{C}\right)$} & \multicolumn{3}{|c|}{ Humidity (\%) } & \multirow{2}{*}{$\begin{array}{l}\text { Pre. } \\
(\mathbf{m m})\end{array}$} & \multirow{2}{*}{$\begin{array}{c}\text { Pan Eva. } \\
(\mathbf{m m})\end{array}$} & \multirow{2}{*}{$\begin{array}{c}\text { Soil Temp. } \\
\left({ }^{\circ} \mathrm{C}\right)\end{array}$} \\
\hline & Avg. & Max. & Min. & Avg. & Max. & Min. & & & \\
\hline \multicolumn{10}{|c|}{ Season 2017} \\
\hline March & 12.2 & 23.0 & 4.0 & 49.7 & 84.0 & 22.0 & 107.1 & 70.2 & 12.0 \\
\hline April & 17.4 & 31.1 & 7.0 & 42.0 & 79.0 & 17.0 & 39.6 & 119.9 & 17.6 \\
\hline May & 24.6 & 39.3 & 12.2 & 30.3 & 75.0 & 16.0 & 19.3 & 164.4 & 23.9 \\
\hline June & 30.4 & 45.7 & 15.2 & 21.4 & 32.0 & 14.0 & 0.0 & 216.0 & 29.4 \\
\hline \multicolumn{10}{|c|}{ Season 2018} \\
\hline March & 14.7 & 30.0 & 2.5 & 42.3 & 78.0 & 18.0 & 15.5 & 98.7 & 11.7 \\
\hline April & 17.1 & 29.7 & 6.2 & 38.4 & 80.0 & 17.0 & 82.7 & 110.5 & 17.4 \\
\hline May & 22.2 & 37.8 & 10.0 & 36.1 & 84.0 & 17.0 & 51.8 & 135.1 & 20.6 \\
\hline June & 30.3 & 45.5 & 17.0 & 21.7 & 30.0 & 13.3 & 0.0 & 211.3 & 27.1 \\
\hline
\end{tabular}

\section{Preparation of Potassium Fertilizer (KCl)}

Two half five gram of potassium chloride $(\mathrm{KCl})$ was dissolved in one liter hot distilled water at $40^{\circ} \mathrm{C}$ with shaking the potassium completely dissolved and several drop of Twin20 were added as a spread material to reduce the surface tension. The plants were sprayed at the morning trice 40,55 and 70 days after planting in both years 2017 and 2018. 


$$
-10077 \text { - }
$$

Table 2. Some physical and chemical properties of Kanipanka soil

\begin{tabular}{c|c|c}
\hline Soil components & Quantities & Unit \\
\hline Sand & 308.0 & $\mathrm{~g} \mathrm{~kg}^{-1}$ \\
Silt & 340.0 & $\mathrm{~g} \mathrm{~kg}^{-1}$ \\
Clay & 352.0 & \\
Textured Class & Clay loam & \\
pH & 7.10 & $\mathrm{dS} \mathrm{m}^{-1}$ \\
EC & 0.38 & $\mathrm{~g} \mathrm{~kg}^{-1}$ \\
Field Capacity & 290.0 & $\mathrm{~g} \mathrm{~kg}^{-1}$ \\
Wilting point & 180.0 & $\mathrm{~g} \mathrm{~kg}^{-1}$ \\
Organic Matter & 8.5 & $\mathrm{~g} \mathrm{~kg}^{-1}$ \\
Available Nitrogen & 32.0 & $\mathrm{~g} \mathrm{~kg}^{-1}$ \\
Available Phosphate & 8.0 & $\mathrm{~g} \mathrm{~kg}^{-1}$ \\
Available Potassium & 73.11 & $\mathrm{~g} \mathrm{~kg}^{-1}$ \\
Carbonate Minerals & 201.2 & $\mathrm{~g} \mathrm{~cm}^{-3}$ \\
Bulk density & 1.32 & $\mathrm{cmolc} \mathrm{kg}^{-1}$ \\
CEC & 33.0 & $\mathrm{meq} \mathrm{L}^{-1}$ \\
Calcium (Ca++) & 2.29 & $\mathrm{meq} \mathrm{L}^{-1}$ \\
Magnesium (Mg++) & 2.53 & $\mathrm{meq} \mathrm{L}^{-1}$ \\
Potassium (K+) & 0.93 & $\mathrm{meq} \mathrm{L}^{-1}$ \\
Sodium (Na+) & 2.10 & $\mathrm{meq} \mathrm{L}^{-1}$ \\
Carbonate (CO3=) & $\mathrm{Nil}$ & $\mathrm{meq} \mathrm{L}^{-1}$ \\
Bicarbonate (HCO3-) & 0.90 & $\mathrm{meq} \mathrm{L}^{-1}$ \\
Chloride (Cl-) & 2.49 & $\mathrm{meq} \mathrm{L}^{-1}$ \\
Sulphate (SO4=) & 2.16 &
\end{tabular}

Table 3. The experimental factors used in the study

\begin{tabular}{|c|c|c|c|}
\hline No. & Factors & Levels & Descriptions \\
\hline \multirow{2}{*}{ First } & \multirow{2}{*}{ Irrigation Intervals } & $\mathrm{I}_{5}$ & 5 days \\
\hline & & $\mathrm{I}_{10}$ & 10 days \\
\hline \multirow{13}{*}{ Second } & \multirow{13}{*}{ Treatments } & $\mathrm{T}_{1}$ & Control (Spray with distilled water). \\
\hline & & $\mathrm{T}_{2}$ & Di-Ammonium Phosphate (DAP). \\
\hline & & $\mathrm{T}_{3}$ & Mycorrhizal Inoculation. \\
\hline & & $\mathrm{T}_{4}$ & Spraying with $\left(2.5 \mathrm{~g} \mathrm{~L}^{-1}\right) \mathrm{KCl}$. \\
\hline & & $\mathrm{T}_{5}$ & Spraying with $\left(3 \mathrm{~g} \mathrm{~L}^{-1}\right)$ Glycyrrhiza glabra extract. \\
\hline & & $\mathrm{T}_{6}$ & Spraying with $\left(6 \mathrm{~g} \mathrm{~L}^{-1}\right)$ Glycyrrhiza glabra extract. \\
\hline & & $\mathrm{T}_{7}$ & Mycorrhizal Inoculation + Spraying with $\left(2.5 \mathrm{~g} \mathrm{~L}^{-1}\right) \mathrm{KCl}$. \\
\hline & & $\mathrm{T}_{8}$ & $\begin{array}{l}\text { Mycorrhizal Inoculation + Spraying with }\left(3 \mathrm{~g} \mathrm{~L}^{-1}\right) \text { Glycyrrhiza } \\
\text { glabra extract. }\end{array}$ \\
\hline & & $\mathrm{T}_{9}$ & $\begin{array}{c}\text { Mycorrhizal Inoculation }+ \text { Spraying with }\left(6 \mathrm{~g} \mathrm{~L}^{-1}\right) \text { Glycyrrhiza } \\
\text { glabra extract. }\end{array}$ \\
\hline & & $\mathrm{T}_{10}$ & $\begin{array}{l}\text { Spraying with }\left(2.5 \mathrm{~g} \mathrm{~L}^{-1}\right) \mathrm{KCl}+\text { Spraying with }\left(3 \mathrm{~g} \mathrm{~L}^{-1}\right) \text { Glycyrrhiza } \\
\text { glabra extract. }\end{array}$ \\
\hline & & $\mathrm{T}_{11}$ & $\begin{array}{l}\text { Spraying with }\left(2.5 \mathrm{~g} \mathrm{~L}^{-1}\right) \mathrm{KCl}+\text { Spraying with }\left(6 \mathrm{~g} \mathrm{~L}^{-1}\right) \text { Glycyrrhiza } \\
\text { glabra extract. }\end{array}$ \\
\hline & & $\mathrm{T}_{12}$ & $\begin{array}{l}\text { Mycorrhizal Inoculation }+ \text { Spraying with }\left(2.5 \mathrm{~g} \mathrm{~L}^{-1}\right) \mathrm{KCl}+ \\
\text { Spraying with }\left(3 \mathrm{~g} \mathrm{~L}^{-1}\right) \text { Glycyrrhiza glabra extract. }\end{array}$ \\
\hline & & $\mathrm{T}_{13}$ & $\begin{array}{l}\text { Mycorrhizal Inoculation + Spraying with }\left(2.5 \mathrm{~g} \mathrm{~L}^{-1}\right) \mathrm{KCl}+ \\
\text { Spraving with }\left(6 \mathrm{~g} \mathrm{~L}^{-1}\right) \text { Glycyrrhiza glabra extract. }\end{array}$ \\
\hline
\end{tabular}




\section{Addition of Chemical Fertilizer}

Six hundred kilograms per hectare of Di-Ammonium Phosphate (DAP) 18:18:0 fertilizer was added in two times, first during the cultivation of the tubers (spares on the furrows), the second addition was after one month from the first addition as recommended for the chemical fertilizer treatment only, (Esho et al., 2009) while half of the recommended were added for the rest of the treatments.

\section{Field Practices}

Each experimental unit (furrow) was $3 \mathrm{~m}$ long and $0.8 \mathrm{~m}$ apart $\left(2.4 \mathrm{~m}^{2}\right)$, each furrows consists of 12 plants in one side. Planting dates were 10 March 2017 and 5 March 2018 at the first and the second season respectively, while the harvesting were accomplished after 100 days on 20 June 2017 and 15 June 2018 at the first and the second season respectively. The furrows within the blocks were divided into 4 groups, each group consists of 4 furrows, the last one was one furrow, and each groups were conducted with a $10 \mathrm{~cm}$ diameter plastic pipes to feeding them with water from the main stream in order to calculate the timing for watering from the main stream to the furrows. The timing was calculate until the water reached the standardized line in each furrow in order to measure the quantity of water that entered the furrow through the plastic pipes in each irrigation intervals 5 and 10 days. The average volume of water and its operation time was calculated to estimate the discharge of sub main irrigation pipe:

$$
Q t=A d
$$

where:

- $Q$ : discharge of sub main $(\mathrm{L} / \mathrm{sec})$.

- $t$ : operation time (sec).

- $A$ : area of furrow $\left(2.4 \mathrm{~m}^{2}\right)$.

- $d$ : depth of irrigation water $(\mathrm{mm})$.

Level furrows were created between rows to ensure uniform water distribution in plots irrigated by furrows. Furrows were closed at the end to prevent runoff and a square meter was used to measure the amounts of applied water. Since the Actual Evapotranspiration (ETa) was calculated using the soil water balance method:

$$
E T_{a}=P+I-D \pm \Delta W
$$

where:

- $E T_{\mathrm{a}}$ : actual evapotranspiration $(\mathrm{mm})$.

- $P:$ is the rainfall $(\mathrm{mm})$.

- $I:$ is the irrigation applied to individual plots (mm).

- $D$ : is the deep percolation.

- $\Delta W$ : is the change in water storage of the soil profile $(\mathrm{mm})$.

Water use efficiency (WUE) and irrigation water use efficiency (IWUE) were calculated from the following equations (Kirda, 2002) and (Howell et al., 1990):

$$
W U E=\frac{\text { Yield }(\mathrm{kg})}{E T a\left(\mathrm{~m}^{\mathrm{a}}\right)}
$$




$$
I W U E=\frac{\text { Yied }(\mathrm{kg})}{\text { Total water applied }\left(\mathrm{m}^{2}\right)}
$$

\section{Statistical Analysis}

A factorial experiment was conducted in split-plot design with three replicates; the first factor (Irrigation intervals) were implemented in the main plots and conducted with Randomized Complete Block Design (RCBD), while the second factor (Treatments) were implemented in the sub plots. All possible comparisons among the means were carried out by using Least Significant Difference (L.S.D) test at a significant level of 5\% after they show their significance in the general test (Al-Rawi and Khalafallah, 1980).

\section{Results}

Water is one of the most essential elements in growing plants, which constitutes more than $80 \%$ of the active cells. Thereby, the amount of applied water during crop irrigation, added time, irrigation methods, quality of added water, and prevailing micrometeorological conditions have found to play limited roles in yield quality and quantity. In Asia, statistics showed that the yields for most crops have increased 100-400\% after irrigation. Irrigation allows farmers to use water in the most efficient way and at the crucial times for the crop instead of being subject to the shortage of rainfall. Water becomes scarce, expensive, and necessitates to be utilized in a scientific manner.

In the first season of irrigation intervals 5 and 10 days were applied after 50 days from sowing and were ended at 96 days after sowing, since, the amount of irrigation water for 5 days interval was cover the most of depleted water at this time. The cumulative depth of irrigation for 5 and 10 days from 1 May 2017 to 15 June 2017 were practically measured and formed to be 369 and $228 \mathrm{~mm}$, respectively. Since the numbers of irrigation were 10 and 6 times for 5 and 10 days of irrigation intervals respectively as shown in Fig. 2. While the amount of actual evapotranspiration for 2017 and 2018 were 529, 423, 515 and $440 \mathrm{~mm}$, respectively (Table 4 by applied Equation 2), while cumulate depth of irrigation and precipitation were 535 and $394 \mathrm{~mm}$ respectively as shown in Fig. 3.

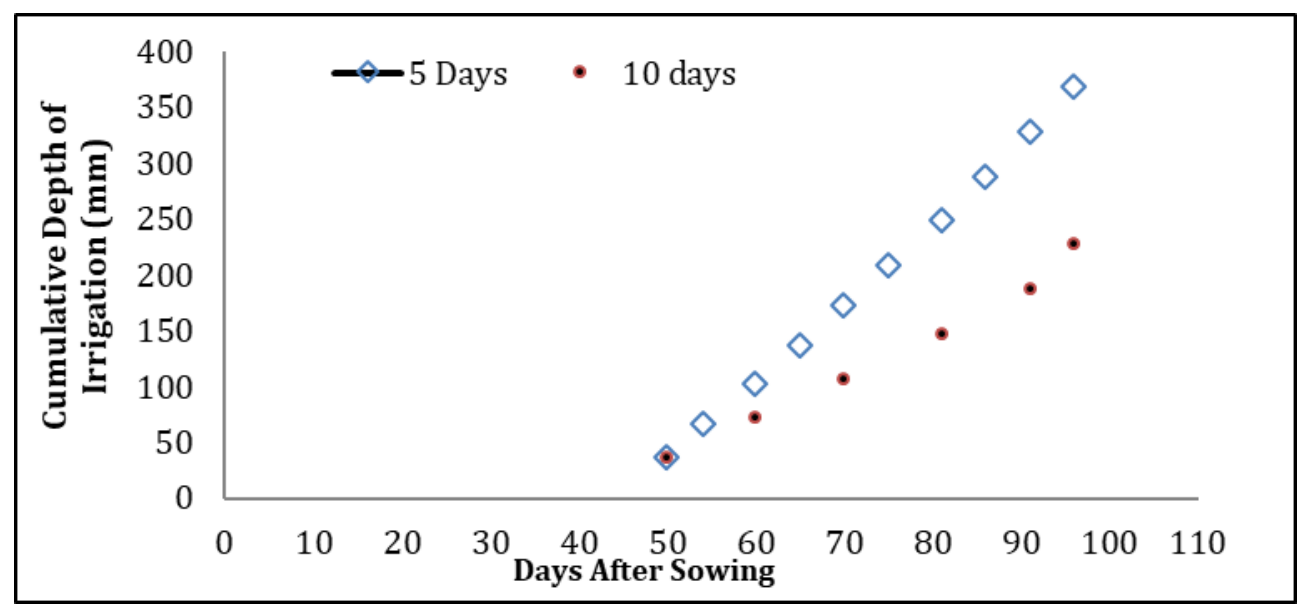

Figure 2. Cumulative depth of irrigation ( $\mathrm{mm}$ ) for 5 and 10 days of irrigation intervals in 2017 


$$
-10080-
$$

Table 4. Actual evapotranspiration (ETa) for 5 and 10 days in 2017 and 2018

\begin{tabular}{c|c|c|c|c}
\hline \multirow{2}{*}{ Component } & \multicolumn{2}{|c|}{ Season 2017 } & \multicolumn{2}{c}{ Season 2018 } \\
\cline { 2 - 5 } & $\mathbf{I}$ & $\mathbf{I}_{\mathbf{1 0}}$ & $\mathbf{I}_{\mathbf{5}}$ & $\mathbf{I}_{\mathbf{1 0}}$ \\
\hline Rainfall (P) (mm) & 166 & 166 & 150 & 150 \\
Irrigation (I) ( mm) & 369 & 228 & 363 & 287 \\
Deep percolation (D) (mm) & 36 & 16 & 34 & 20 \\
$\Delta \mathrm{W}(\mathrm{mm})$ & 30 & 45 & 36 & 23 \\
Eta (mm) & 529 & 423 & 515 & 440 \\
\hline
\end{tabular}

Eta $\left(\mathrm{m}^{\mathrm{a}}\right)$ for $\left(\mathrm{I}_{5}-2017\right)=1.104+0.384=1.488 \mathrm{~m}^{\mathrm{a}}$

Eta $\left(\mathrm{m}^{2}\right)$ for $\left(\mathrm{I}_{10}-2017\right)=0.680+0.468=1.148 \mathrm{~m}^{\mathrm{a}}$

Eta $\left(\mathrm{m}^{2}\right)$ for $\left(\mathrm{I}_{5}-2018\right)=1.089+0.364=1.453 \mathrm{~m}^{2}$

Eta $\left(\mathrm{m}^{2}\right)$ for $\left(\mathrm{I}_{10}-2018\right)=0.681+0.367=1.228 \mathrm{~m}^{\mathrm{a}}$

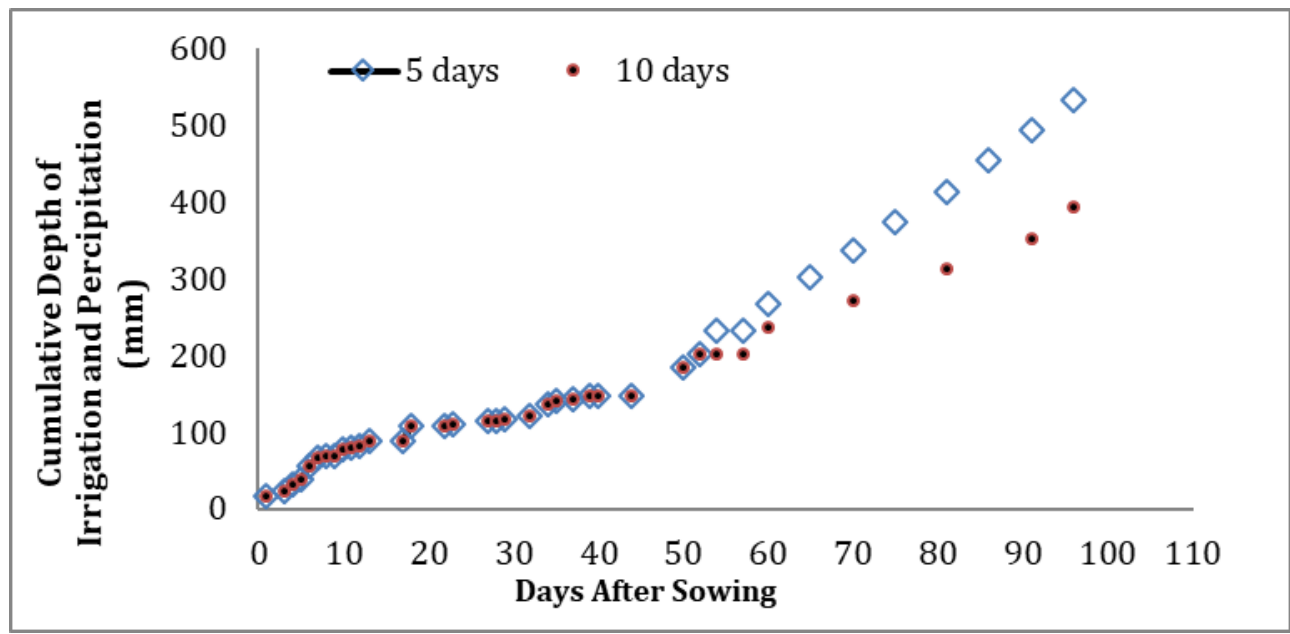

Figure 3. Cumulative depth of irrigation and precipitation ( $\mathrm{mm}$ ) for 5 and 10 days of irrigation intervals in 2017

In the season 2018 the irrigation intervals 5 and 10 days was applied from the sowing date and were ended at 95 days after sowing, the amount of irrigation water for 5 days interval which cover the most of depleted from 5 March 2018 to 10 June 2018 were practically measured 363 and $287 \mathrm{~mm}$, respectively. Since the numbers of irrigation were 9 and 5 times for 5 and 10 days of irrigation intervals respectively as shown in Fig. 4. While accumulate depth irrigation and precipitation were 513 and $437 \mathrm{~mm}$, respectively as shown in Fig. 5. These results are in agreement with the findings of several other researches (Ati et al., 2012; Ati and Nafaou, 2012). Gander and Tanner (1976) showed that mild water stress of -3 to -5 bars greatly reduce leaf expansion in potatoes, and for best tuber yields, a 120-150 day potato crop requires $508-698.5 \mathrm{~mm}$ of the water.

The data in Table 5 and Appendix 1 and 2 show the effect of the irrigation intervals on the studied characters, significant differences were observed among all of the studied characters at the first, second and average of both seasons with exception of WUE in the first season this may be due to that rain fed in this season distributed throughout the growing season in the way that the deficit does not cause any reduction in the yield. The 5 days irrigation intervals achieved the highest values of WUE and in the second and average of both seasons with 7.085 and $6.802 \mathrm{~kg} \mathrm{~m}^{-3}$, respectively, while the 10 days irrigation intervals achieved lowest 


$$
-10081 \text { - }
$$

values with 6.144 and $6.439 \mathrm{~kg} \mathrm{~m}^{-3}$, respectively. This agrees with the finding of Nagaz et al. (2007), which concluded that WUE varied around 8-9, 6-8 and 11-14 $\mathrm{kg} \mathrm{m}^{-3}$ for autumn and spring planted potato, respectively in Southern Tunisia. Rashidi and Gholami (2008) reported that WUE of potato in Iran ranged from 1.92 to $5.25 \mathrm{~kg} \mathrm{~m}^{-3}$. Erdem et al. (2006) reported that potatoes plant was grown under furrow and drip irrigation methods and three regimens irrigation applied when 30,50 , and $70 \%$ of the available water was consumed, water use efficiency values increased from 4.70 to $6.63 \mathrm{~kg} \mathrm{~m}^{-3}$ for furrow-irrigated treatments, and from 5.19 to $9.47 \mathrm{~kg} \mathrm{~m}^{-3}$ for drip-irrigated treatments.

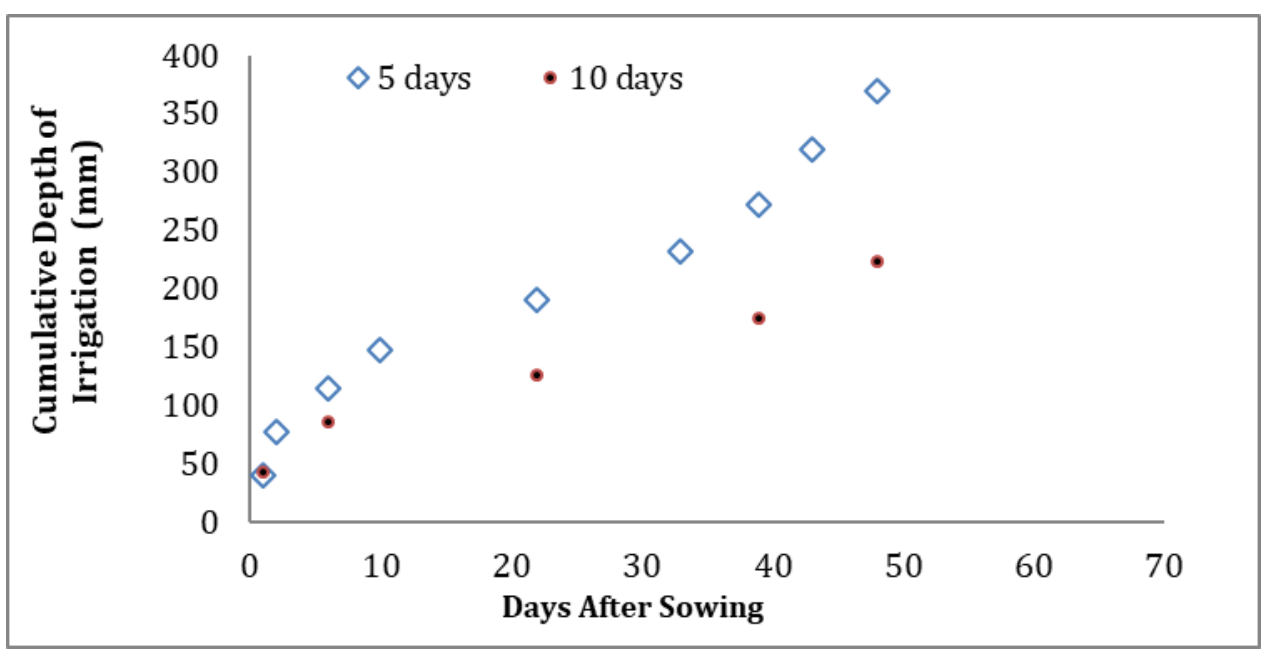

Figure 4. Cumulative depth of irrigation ( $\mathrm{mm}$ ) for 5 and 10 days irrigation intervals in 2018

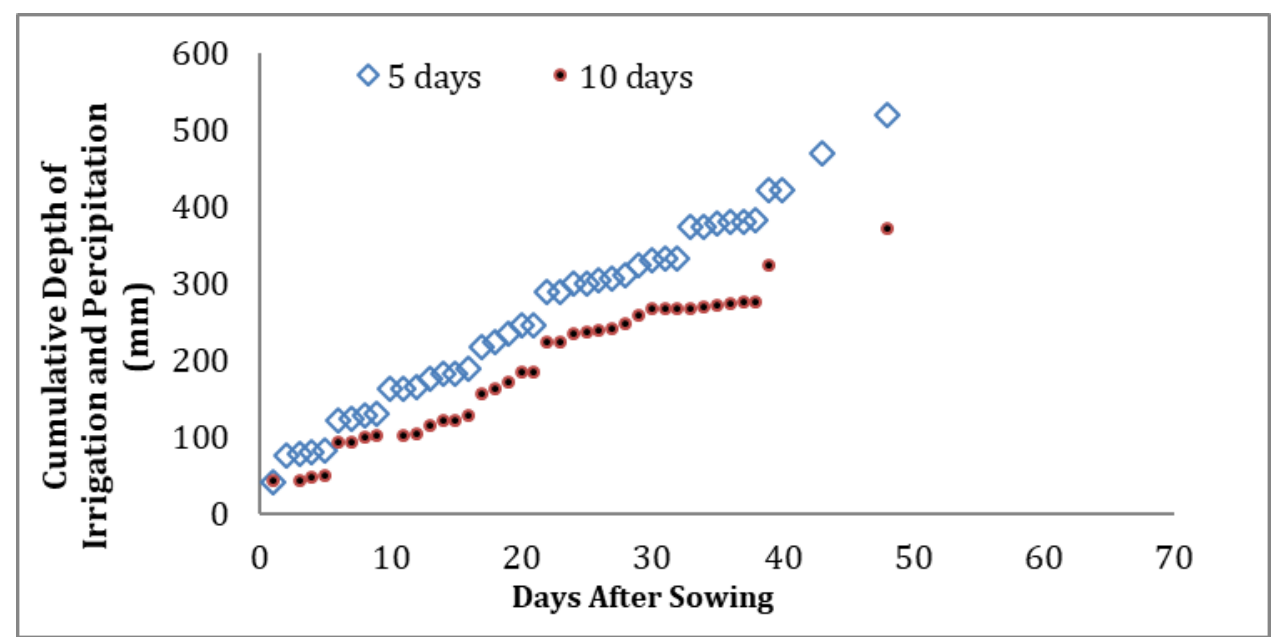

Figure 5. Cumulative depth of irrigation and precipitation ( $\mathrm{mm})$ for 5 and 10 days irrigation intervals in 2018

Concerning the IWUE in the first, second and average of both seasons the 10 days irrigation intervals gave the maximum values with $11.352,11.281$ and $11.316 \mathrm{~kg} \mathrm{~m}^{-3}$ respectively, while the 5 days irrigation intervals gave the lowest values with 8.788, 9.293 and $9.041 \mathrm{~kg} \mathrm{~m}^{-3}$ respectively. Total yield gave the maximum values in the use of the 5 days 
irrigation intervals at the first, second and the average of both seasons with 40.418, 42.886, and 41.652 tons hectare ${ }^{-1}$ respectively and overcome the yields of the 10 days intervals which gave $32.205,31.431$, and 31.818 tons hectare ${ }^{-1}$ at the first, second and the average of both seasons, respectively.

Table 5. Effect of irrigation intervals on WUE, IWUE and total yield

\begin{tabular}{|c|c|c|c|}
\hline $\begin{array}{l}\text { Irrigation Interval } \\
\text { (A) }\end{array}$ & $\begin{array}{c}\text { WUE } \\
\left(\mathrm{kg} \mathrm{m}^{-3}\right)\end{array}$ & $\begin{array}{c}\text { IWUE } \\
\left(\mathbf{k g ~ m}^{-3}\right)\end{array}$ & $\begin{array}{c}\text { Total yield } \\
(\text { tons hectare } \\
\end{array}$ \\
\hline \multicolumn{4}{|c|}{ First Season } \\
\hline $\mathrm{I}_{5}$ & $6.520^{\mathrm{a}}$ & $8.788^{b}$ & $40.418^{a}$ \\
\hline $\mathrm{I}_{10}$ & $6.734^{\mathrm{a}}$ & $11.352^{\mathrm{a}}$ & $32.205^{b}$ \\
\hline L.S.D $(p \leq 0.05)$ & n.s & 1.193 & 2.012 \\
\hline \multicolumn{4}{|c|}{ Second Season } \\
\hline $\mathrm{I}_{5}$ & $7.085^{\mathrm{a}}$ & $9.293^{b}$ & $42.886^{\mathrm{a}}$ \\
\hline $\mathrm{I}_{10}$ & $6.144^{b}$ & $11.281^{\mathrm{a}}$ & $31.431^{\mathrm{b}}$ \\
\hline L.S.D $(p \leq 0.05)$ & 0.761 & 1.280 & 4.117 \\
\hline \multicolumn{4}{|c|}{ Average of Both Seasons } \\
\hline $\mathrm{I}_{5}$ & $6.802^{a}$ & $9.041^{\mathrm{a}}$ & $41.652^{a}$ \\
\hline $\mathrm{I}_{10}$ & $6.439^{b}$ & $11.316^{\mathrm{b}}$ & $31.818^{\mathrm{b}}$ \\
\hline L.S.D $(p \leq 0.05)$ & 0.311 & 0.565 & 1.479 \\
\hline
\end{tabular}

Table 6A and Appendix 1 illustrated the effect of the treatments on WUE, IWUE and yield plant ${ }^{-1}$ at the first season, the treatment had significant effect on all of the studied characters. The maximum values of WUE, IWUE and total yield achieved by $T_{3}$ with $8.141 \mathrm{~kg} \mathrm{~m}^{-3}, 12.297 \mathrm{~kg} \mathrm{~m}^{-3}$ and 44.912 tons hectare ${ }^{-1}$ respectively, while $T_{1}$ gave the minimum values with $4.753 \mathrm{~kg} \mathrm{~m}^{-3}, 7.236 \mathrm{~kg} \mathrm{~m}^{-3}$ and 25.984 tons hectare ${ }^{-1}$ respectively.

Table 6A. Effect of the biotechnological treatments on WUE, IWUE and tota yield at the first season

\begin{tabular}{|c|c|c|c|}
\hline $\begin{array}{l}\text { Treatments } \\
\text { (B) }\end{array}$ & $\begin{array}{c}\text { WUE } \\
\left(\mathrm{kg} \mathrm{m}^{-3}\right)\end{array}$ & $\begin{array}{c}\text { IWUE } \\
\left(\mathrm{kg} \mathrm{m}^{-3}\right)\end{array}$ & $\begin{array}{c}\text { Total yield } \\
\left.\text { (tons hectare }^{-1}\right)\end{array}$ \\
\hline \multicolumn{4}{|c|}{ First Season } \\
\hline $\mathrm{T}_{1}$ & $4.753^{d}$ & $7.236^{\mathrm{d}}$ & $25.984^{\mathrm{d}}$ \\
\hline $\mathrm{T}_{2}$ & $7.092^{a b}$ & $10.746^{\mathrm{ab}}$ & $38.984^{b}$ \\
\hline $\mathrm{T}_{3}$ & $8.141^{\mathrm{a}}$ & $12.297^{\mathrm{a}}$ & $44.912^{\mathrm{a}}$ \\
\hline $\mathrm{T}_{4}$ & $6.845^{b c}$ & $10.371^{b c}$ & $37.634^{b}$ \\
\hline $\mathrm{T}_{5}$ & $5.810^{\mathrm{cd}}$ & $8.872^{\mathrm{cd}}$ & $31.654^{\mathrm{cd}}$ \\
\hline $\mathrm{T}_{6}$ & $6.872^{b c}$ & $10.404^{b c}$ & $37.812^{b}$ \\
\hline $\mathrm{T}_{7}$ & $7.178^{a b}$ & $10.908^{a b}$ & $39.331^{\mathrm{ab}}$ \\
\hline $\mathrm{T}_{8}$ & $6.604 \mathrm{bc}$ & $10.072 \mathrm{bc}$ & $36.033 \mathrm{bc}$ \\
\hline $\mathrm{T}_{9}$ & 6.203 bc & $9.440^{\mathrm{bc}}$ & $33.924 \mathrm{bc}$ \\
\hline $\mathrm{T}_{10}$ & $6.676^{b c}$ & $10.201 \mathrm{bc}$ & $36.347^{b c}$ \\
\hline $\mathrm{T}_{11}$ & $6.629^{b c}$ & $9.947^{b c}$ & $36.856^{b c}$ \\
\hline $\mathrm{T}_{12}$ & $6.642^{b c}$ & $10.115^{b c}$ & $36.293^{b c}$ \\
\hline $\mathrm{T}_{13}$ & $6.705^{b c}$ & $10.296^{b c}$ & $36.284^{b c}$ \\
\hline $\mathbf{L S D}_{(\mathrm{p} \leq 0.05)}$ & 1.079 & 1.654 & 5.940 \\
\hline
\end{tabular}


This may be due to the use of arbuscular mycorrhizal fungi (AMF) mitigates the effects of this stress in a sustainable way and given the increase in the tolerance to water deficit stress in plants inoculated with these fungi; however, the exact mechanism is unknown because the response depends on the water-deficit stress type and is specific to the AMF and the plant. These mechanisms may include modifications in the content of plant hormones, such as strigolactones, jasmonic acid (JA) and absicic acid (ABA). The JA appears to be involved in the stress signal in mycorrhizal plants through an increase of ABA concentrations and, at the same time, ABA has a regulating effect on strigolactones concentrations. Also, there is improvement of plant water status, stomatal conductance, nutritional status and plant responses to cope with a water deficit, such as osmotic adjustment, and antioxidant activity. These modifications cause an increase in $\mathrm{CO}_{2}$ assimilation and photoassimilates production, improving plant growth as well as the yield during a drought.

The results in Table $6 B$ and Appendix 1 revealed that the treatments significantly influenced on WUE, IWUE and yield plant ${ }^{-1}$ during the second season 2018. The highest values were obtained by $T_{11}$ with $7.495 \mathrm{~kg} \mathrm{~m}^{-3}, 11.655 \mathrm{~kg} \mathrm{~m}^{-3}$ and 42.106 tons hectare $^{-1}$ respectively, while the lowest value was recorded by $T_{1}$ with $5.334 \mathrm{~kg} \mathrm{~m}^{-3}$, $8.456 \mathrm{~kg} \mathrm{~m}^{-3}$, and 29.678 tons hectare ${ }^{-1}$ for WUE, IWUE and total yield respectively. These results is agree with the study of Ati et al. (2013) which they stated that potassium humate had a great impact on tuber of potato and water use efficiency in the Abu-Graib Region, Iraq. In their study potato was grown under drip irrigation with three treatments: irrigation applied when evaporation $75 \%, 100 \%$ and $125 \%$ from pan A, and three potassium humate fertilizers: $0,1.2$ and $2.4 \mathrm{~kg} \mathrm{ha}^{-1}$ with three times additions. The seasonal potato evapotranspiration ranged from $267 \mathrm{~mm}$ to $372 \mathrm{~mm}$. The drip irrigation treatments had significant effecting tuber yield of potato recorder 29.530, 27.630 and $24.880 \mathrm{~kg} \mathrm{ha}^{-1}$ for $125 \%, 100 \%$ and $75 \%$ from pan A evapotranspiration, respectively. Humus fertilizers addition has the lowest value of ETa $309 \mathrm{~mm}$ and maximum value of yield $29300 \mathrm{~kg} \mathrm{ha}^{-1}$.

Table 6B. Effect of the biotechnological treatments on WUE, IWUE and total yield at the second season

\begin{tabular}{|c|c|c|c|}
\hline $\begin{array}{l}\text { Treatments } \\
\text { (B) }\end{array}$ & $\begin{array}{c}\text { WUE } \\
\left(\mathrm{kg} \mathrm{m}^{-3}\right)\end{array}$ & $\begin{array}{c}\text { IWUE } \\
\left(\mathrm{kg} \mathrm{m}^{-3}\right)\end{array}$ & $\begin{array}{c}\text { Total yield } \\
\left.\text { (tons hectare }^{-1}\right)\end{array}$ \\
\hline \multicolumn{4}{|c|}{ Second Season } \\
\hline $\mathrm{T}_{1}$ & $5.334^{\mathrm{d}}$ & $8.456^{\mathrm{e}}$ & $29.678^{e}$ \\
\hline $\mathrm{T}_{2}$ & $7.155^{a b}$ & $11.346^{\mathrm{ab}}$ & $39.809^{a b c}$ \\
\hline $\mathrm{T}_{3}$ & $7.337^{a b}$ & $11.280^{\mathrm{ab}}$ & $41.453^{a b}$ \\
\hline $\mathrm{T}_{4}$ & $5.957^{\mathrm{cd}}$ & $9.286^{\mathrm{cde}}$ & 33.424 cde \\
\hline $\mathrm{T}_{5}$ & $6.228 \mathrm{bcd}$ & 9.793 bcde & 34.799 abcde \\
\hline $\mathrm{T}_{6}$ & $6.910^{a b c}$ & 10.688 abcd & 38.924 abcd \\
\hline $\mathrm{T}_{7}$ & $7.301^{a b}$ & $11.167^{\mathrm{ab}}$ & $41.351^{\mathrm{ab}}$ \\
\hline $\mathrm{T}_{8}$ & $6.175^{\mathrm{bcd}}$ & $9.676^{\text {bcde }}$ & 34.564 bcde \\
\hline $\mathrm{T}_{9}$ & $5.738^{\mathrm{cd}}$ & $8.977^{\text {de }}$ & 32.142 de \\
\hline $\mathrm{T}_{10}$ & $7.085^{a b}$ & $10.901^{a b c}$ & $40.014^{a b c}$ \\
\hline $\mathrm{T}_{11}$ & $7.495^{\mathrm{a}}$ & $11.655^{\mathrm{a}}$ & $42.106^{\mathrm{a}}$ \\
\hline $\mathrm{T}_{12}$ & $6.446^{\mathrm{abcd}}$ & 10.092 abcde & 36.089 abcde \\
\hline $\mathrm{T}_{13}$ & $6.826^{a b c}$ & $10.416^{\mathrm{abcd}}$ & 38.709 abcd \\
\hline $\mathbf{L S D}_{(p \leq 0.05)}$ & 1.257 & 1.846 & 7.318 \\
\hline
\end{tabular}


Table 6C and Appendix 2 showed the effect of the treatments on WUE, IWUE and total yield. The differences among treatments were significant at the average of both seasons. $T_{3}$ gave the maximum values for all of the characters with $7.739 \mathrm{~kg} \mathrm{~m}^{-3}$, $11.789 \mathrm{~kg} \mathrm{~m}^{-3}$, and 43.183 tons hectar ${ }^{-1}$ respectively, however the minimum values recorded in $T_{1}$ with $5.034 \mathrm{~kg} \mathrm{~m}^{-3}, 7.846 \mathrm{~kg} \mathrm{~m}^{-3}$ and 27.831 tons hectar ${ }^{-1}$ respectively. The results agreement with the finding of several other researches. Goussous and Mohammad (2009) reported that Arbuscular Mycorrhizal Fungi (AMF) and plant roots improve water and nutrient uptake such as phosphorus, nitrogen and micronutrients, thus enhance potato plants growth, and yield. AMF can produce glycoprotein glomalin, which is act similar a glue, binding carbon, nitrogen and other biological components of soil to the mineral components, clay and sand, that has an important role for increased soil organic matter, and consequently collected highly water stability (Duc, 2017). In addition, under drought condition, direct water uptake from soil into the host plant can improved by interlacing external hyphae of mycorrhizae, thus, it is believed that has resistance to drought condition by many mechanisms including; osmotic adjustment and altering display of stomatal conductance (Qiang-Sheng et al., 2006).

Table 6C. Effect of the treatments on WUE, IWUE and total yield at the average of both seasons

\begin{tabular}{|c|c|c|c|}
\hline $\begin{array}{l}\text { Treatments } \\
\text { (B) }\end{array}$ & $\begin{array}{c}\text { WUE } \\
\left(\mathbf{k g ~ m}^{-3}\right)\end{array}$ & $\begin{array}{c}\text { IWUE } \\
\left(\mathrm{kg} \mathrm{m}^{-3}\right)\end{array}$ & $\begin{array}{c}\text { Total yield } \\
\left(\text { tons hectare }{ }^{-1}\right)\end{array}$ \\
\hline \multicolumn{4}{|c|}{ Average of Both Seasons } \\
\hline $\mathrm{T}_{1}$ & $5.043^{\mathrm{d}}$ & $7.846^{\mathrm{e}}$ & $27.831^{\mathrm{e}}$ \\
\hline $\mathrm{T}_{2}$ & $7.123 \mathrm{abc}$ & $11.046^{\mathrm{ab}}$ & $39.396 \mathrm{abc}$ \\
\hline $\mathrm{T}_{3}$ & $7.739^{\mathrm{a}}$ & $11.789^{\mathrm{a}}$ & $43.183^{\mathrm{a}}$ \\
\hline $\mathrm{T}_{4}$ & $6.401 \mathrm{~cd}$ & 9.829 bcd & $35.529^{\mathrm{cd}}$ \\
\hline $\mathrm{T}_{5}$ & $6.019^{d}$ & $9.332^{\mathrm{cd}}$ & $33.226^{\mathrm{d}}$ \\
\hline $\mathrm{T}_{6}$ & $6.891^{\mathrm{bc}}$ & $10.546^{\mathrm{bc}}$ & $38.368 \mathrm{bc}$ \\
\hline $\mathrm{T}_{7}$ & $7.240^{\mathrm{ab}}$ & $11.037 \mathrm{ab}$ & $40.341^{\mathrm{ab}}$ \\
\hline $\mathrm{T}_{8}$ & $6.390^{\mathrm{cd}}$ & 9.874 bcd & $35.298^{\mathrm{cd}}$ \\
\hline $\mathrm{T}_{9}$ & $5.970^{\mathrm{d}}$ & $9.208^{d}$ & $33.033^{\mathrm{d}}$ \\
\hline $\mathrm{T}_{10}$ & $6.881 \mathrm{bc}$ & $10.551^{\mathrm{bc}}$ & $38.180^{\mathrm{bc}}$ \\
\hline $\mathrm{T}_{11}$ & $7.062 \mathrm{abc}$ & $10.801^{\mathrm{ab}}$ & $39.481 \mathrm{abc}$ \\
\hline $\mathrm{T}_{12}$ & 6.544 bcd & 10.104 bcd & 36.191 bcd \\
\hline $\mathrm{T}_{13}$ & $6.766^{\text {bcd }}$ & $10.356^{\text {bcd }}$ & 37.497 bcd \\
\hline $\operatorname{LSD}_{(p \leq 0.05)}$ & 0.818 & 1.223 & 4.653 \\
\hline
\end{tabular}

The data in Table $7 A, 7 B$ and $7 C$ and Appendix 1 and 2 reveal no significant differences for the interaction effects of irrigation intervals and the treatments on WUE, IWUE and total yield during the first season 2107, the second season 2018 and the average of both seasons.

Data in Table 8 and Appendix 2 show that seasons had no significant effect on WUE, IWUE and total yield. 


$$
-10085 \text { - }
$$

Table 7A. Interaction effects of irrigation intervals and treatments on WUE, IWUE and total yield at the first season

\begin{tabular}{|c|c|c|c|}
\hline Irrigation Interval $\times$ Treatments $(\mathbf{A} \times \mathbf{B})$ & $\begin{array}{c}\text { WUE } \\
\left(\mathrm{kg} \mathrm{m}^{-3}\right)\end{array}$ & $\begin{array}{l}\text { IWUE } \\
\left(\mathrm{kg} \mathrm{m}^{-3}\right)\end{array}$ & 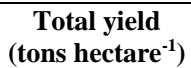 \\
\hline \multicolumn{4}{|c|}{ First Season } \\
\hline $\mathrm{I}_{5} \times \mathrm{T}_{1}$ & $4.593^{\mathrm{a}}$ & $6.191^{\mathrm{a}}$ & $28.472^{\mathrm{a}}$ \\
\hline $\mathrm{I}_{5} \times \mathrm{T}_{2}$ & $7.155^{\mathrm{a}}$ & $9.643^{\mathrm{a}}$ & $44.353^{\text {a }}$ \\
\hline $\mathrm{I}_{5} \times \mathrm{T}_{3}$ & $8.441^{\mathrm{a}}$ & $11.377^{\text {a }}$ & $52.324^{\mathrm{a}}$ \\
\hline $\mathrm{I}_{5} \times \mathrm{T}_{4}$ & $6.914^{\mathrm{a}}$ & $9.319^{\mathrm{a}}$ & $42.859^{\mathrm{a}}$ \\
\hline $\mathrm{I}_{5} \times \mathrm{T}_{5}$ & $5.459^{a}$ & $7.358^{\mathrm{a}}$ & $33.840^{\mathrm{a}}$ \\
\hline $\mathrm{I}_{5} \times \mathrm{T}_{6}$ & $6.986^{\mathrm{a}}$ & $9.416^{\mathrm{a}}$ & $43.307^{\mathrm{a}}$ \\
\hline $\mathrm{I}_{5} \times \mathrm{T}_{7}$ & $7.060^{\mathrm{a}}$ & $9.515^{\mathrm{a}}$ & $43.763^{\mathrm{a}}$ \\
\hline $\mathrm{I}_{5} \times \mathrm{T}_{8}$ & $6.280^{\mathrm{a}}$ & $8.465^{\mathrm{a}}$ & $38.931^{\mathrm{a}}$ \\
\hline $\mathrm{I}_{5} \times \mathrm{T}_{9}$ & $6.015^{\mathrm{a}}$ & $8.107^{\mathrm{a}}$ & $37.284^{\mathrm{a}}$ \\
\hline $\mathrm{I}_{5} \times \mathrm{T}_{10}$ & $6.236^{\mathrm{a}}$ & $8.405^{\mathrm{a}}$ & $38.657^{\mathrm{a}}$ \\
\hline $\mathrm{I}_{5} \times \mathrm{T}_{11}$ & $7.272^{\mathrm{a}}$ & $9.801^{\mathrm{a}}$ & $45.077^{\mathrm{a}}$ \\
\hline $\mathrm{I}_{5} \times \mathrm{T}_{12}$ & $6.395^{\mathrm{a}}$ & $8.619^{a}$ & $39.642^{\mathrm{a}}$ \\
\hline $\mathrm{I}_{5} \times \mathrm{T}_{13}$ & $5.956^{\mathrm{a}}$ & $8.028^{\mathrm{a}}$ & $36.923^{\mathrm{a}}$ \\
\hline $\mathrm{I}_{10} \times \mathrm{T}_{1}$ & $4.913^{\mathrm{a}}$ & $8.282^{\mathrm{a}}$ & $23.496^{\mathrm{a}}$ \\
\hline $\mathrm{I}_{10} \times \mathrm{T}_{2}$ & $7.029^{\mathrm{a}}$ & $11.848^{\mathrm{a}}$ & $33.615^{\mathrm{a}}$ \\
\hline $\mathrm{I}_{10} \times \mathrm{T}_{3}$ & $7.841^{\mathrm{a}}$ & $13.218^{\mathrm{a}}$ & $37.500^{\mathrm{a}}$ \\
\hline $\mathrm{I}_{10} \times \mathrm{T}_{4}$ & $6.777^{\mathrm{a}}$ & $11.424^{\mathrm{a}}$ & $32.410^{\mathrm{a}}$ \\
\hline $\mathrm{I}_{10} \times \mathrm{T}_{5}$ & $6.161^{\mathrm{a}}$ & $10.387^{a}$ & $29.467^{\mathrm{a}}$ \\
\hline $\mathrm{I}_{10} \times \mathrm{T}_{6}$ & $6.757^{\mathrm{a}}$ & $11.391^{\mathrm{a}}$ & $32.318^{\mathrm{a}}$ \\
\hline $\mathrm{I}_{10} \times \mathrm{T}_{7}$ & $7.297^{\mathrm{a}}$ & $12.301^{\mathrm{a}}$ & $34.900^{\mathrm{a}}$ \\
\hline $\mathrm{I}_{10} \times \mathrm{T}_{8}$ & $6.928^{a}$ & $11.679^{\mathrm{a}}$ & $33.134^{\mathrm{a}}$ \\
\hline $\mathrm{I}_{10} \times \mathrm{T}_{9}$ & $6.391^{\mathrm{a}}$ & $10.773^{\mathrm{a}}$ & $30.564^{\mathrm{a}}$ \\
\hline $\mathrm{I}_{10} \times \mathrm{T}_{10}$ & $7.117^{\mathrm{a}}$ & $11.997^{\mathrm{a}}$ & $34.037^{\mathrm{a}}$ \\
\hline $\mathrm{I}_{10} \times \mathrm{T}_{11}$ & $5.987^{\mathrm{a}}$ & $10.093^{\mathrm{a}}$ & $28.635^{\mathrm{a}}$ \\
\hline $\mathrm{I}_{10} \times \mathrm{T}_{12}$ & $6.888^{a}$ & $11.612^{\mathrm{a}}$ & $32.943^{\mathrm{a}}$ \\
\hline $\mathrm{I}_{10} \times \mathrm{T}_{13}$ & $7.453^{\mathrm{a}}$ & $12.564^{\mathrm{a}}$ & $35.646^{\mathrm{a}}$ \\
\hline L.S.D $(p \leq 0.05)$ & n.s & n.s & n.s \\
\hline
\end{tabular}

Table 7B. Interaction effects of irrigation intervals and treatments on WUE, IWUE and total yield at the second season

\begin{tabular}{|c|c|c|c|}
\hline Irrigation Interval $\times$ Treatments $(A \times B)$ & $\begin{array}{c}\text { WUE } \\
\left(\mathrm{kg} \mathrm{m}^{-3}\right) \\
\end{array}$ & $\begin{array}{c}\text { IWUE } \\
\left(\mathrm{kg} \mathrm{m}^{-3}\right)\end{array}$ & $\begin{array}{c}\text { Total yield } \\
\left(\text { tons hectare }^{-1}\right)\end{array}$ \\
\hline \multicolumn{4}{|c|}{ Second Season } \\
\hline $\mathrm{I}_{5} \times \mathrm{T}_{1}$ & $5.102^{a}$ & $6.693^{\mathrm{a}}$ & $30.886^{\mathrm{a}}$ \\
\hline $\mathrm{I}_{5} \times \mathrm{T}_{2}$ & $6.836^{\mathrm{a}}$ & $8.966^{\mathrm{a}}$ & $41.377^{\mathrm{a}}$ \\
\hline $\mathrm{I}_{5} \times \mathrm{T}_{3}$ & $8.359^{\mathrm{a}}$ & $10.964^{\mathrm{a}}$ & $50.598^{a}$ \\
\hline $\mathrm{I}_{5} \times \mathrm{T}_{4}$ & $6.296^{\mathrm{a}}$ & $8.258^{\mathrm{a}}$ & $38.109^{\mathrm{a}}$ \\
\hline $\mathrm{I}_{5} \times \mathrm{T}_{5}$ & $6.266^{\mathrm{a}}$ & $8.219^{\mathrm{a}}$ & $37.928^{\mathrm{a}}$ \\
\hline $\mathrm{I}_{5} \times \mathrm{T}_{6}$ & $7.625^{\mathrm{a}}$ & $10.002^{\mathrm{a}}$ & $46.156^{\mathrm{a}}$ \\
\hline $\mathrm{I}_{5} \times \mathrm{T}_{7}$ & $8.537^{\mathrm{a}}$ & $11.198^{\mathrm{a}}$ & $51.678^{\mathrm{a}}$ \\
\hline $\mathrm{I}_{5} \times \mathrm{T}_{8}$ & $6.341^{\mathrm{a}}$ & $8.318^{\mathrm{a}}$ & $38.385^{\mathrm{a}}$ \\
\hline $\mathrm{I}_{5} \times \mathrm{T}_{9}$ & $5.947^{\mathrm{a}}$ & $7.800^{\mathrm{a}}$ & $35.996^{\mathrm{a}}$ \\
\hline $\mathrm{I}_{5} \times \mathrm{T}_{10}$ & $8.040^{\mathrm{a}}$ & $10.546^{\mathrm{a}}$ & $48.668^{\mathrm{a}}$ \\
\hline $\mathrm{I}_{5} \times \mathrm{T}_{11}$ & $8.032^{\mathrm{a}}$ & $10.536^{\mathrm{a}}$ & $48.619^{a}$ \\
\hline $\mathrm{I}_{5} \times \mathrm{T}_{12}$ & $6.645^{\mathrm{a}}$ & $8.716^{\mathrm{a}}$ & $40.223^{\mathrm{a}}$ \\
\hline $\mathrm{I}_{5} \times \mathrm{T}_{13}$ & $8.078^{a}$ & $10.596^{\mathrm{a}}$ & $48.900^{\mathrm{a}}$ \\
\hline $\mathrm{I}_{10} \times \mathrm{T}_{1}$ & $5.565^{\mathrm{a}}$ & $10.218^{a}$ & $28.470^{a}$ \\
\hline $\mathrm{I}_{10} \times \mathrm{T}_{2}$ & $7.475^{\mathrm{a}}$ & $13.725^{\mathrm{a}}$ & $38.241^{\mathrm{a}}$ \\
\hline $\mathrm{I}_{10} \times \mathrm{T}_{3}$ & $6.315^{\mathrm{a}}$ & $11.596^{\mathrm{a}}$ & $32.309^{a}$ \\
\hline $\mathrm{I}_{10} \times \mathrm{T}_{4}$ & $5.618^{a}$ & $10.315^{a}$ & $28.739^{a}$ \\
\hline $\mathrm{I}_{10} \times \mathrm{T}_{5}$ & $6.190^{\mathrm{a}}$ & $11.366^{\mathrm{a}}$ & $31.669^{\mathrm{a}}$ \\
\hline $\mathrm{I}_{10} \times \mathrm{T}_{6}$ & $6.195^{\mathrm{a}}$ & $11.375^{\mathrm{a}}$ & $31.692^{\mathrm{a}}$ \\
\hline $\mathrm{I}_{10} \times \mathrm{T}_{7}$ & $6.064^{\mathrm{a}}$ & $11.135^{\mathrm{a}}$ & $31.024^{\mathrm{a}}$ \\
\hline $\mathrm{I}_{10} \times \mathrm{T}_{8}$ & $6.009^{\mathrm{a}}$ & $11.034^{\mathrm{a}}$ & $30.742^{\mathrm{a}}$ \\
\hline $\mathrm{I}_{10} \times \mathrm{T}_{9}$ & $5.530^{\mathrm{a}}$ & $10.153^{a}$ & $28.288^{\mathrm{a}}$ \\
\hline $\mathrm{I}_{10} \times \mathrm{T}_{10}$ & $6.130^{\mathrm{a}}$ & $11.256^{\mathrm{a}}$ & $31.360^{\mathrm{a}}$ \\
\hline $\mathrm{I}_{10} \times \mathrm{T}_{11}$ & $6.958^{\mathrm{a}}$ & $12.775^{\mathrm{a}}$ & $35.594^{\mathrm{a}}$ \\
\hline $\mathrm{I}_{10} \times \mathrm{T}_{12}$ & $6.246^{\mathrm{a}}$ & $11.469^{\mathrm{a}}$ & $31.955^{\mathrm{a}}$ \\
\hline $\mathrm{I}_{10} \times \mathrm{T}_{13}$ & $5.574^{\mathrm{a}}$ & $10.235^{\mathrm{a}}$ & $28.518^{a}$ \\
\hline L.S.D $(p \leq 0.05)$ & n.s & n.s & n.s \\
\hline
\end{tabular}


Table $7 C$. Interaction effects of irrigation intervals and treatments on WUE, IWUE and total yield at the average of both seasons

\begin{tabular}{|c|c|c|c|}
\hline Irrigation Interval $\times$ Treatments $(\mathbf{A} \times \mathbf{B})$ & $\begin{array}{c}\text { WUE } \\
\left(\mathrm{kg} \mathrm{m}^{-3}\right)\end{array}$ & $\begin{array}{c}\text { IWUE } \\
\left(\mathrm{kg} \mathrm{m}^{-3}\right)\end{array}$ & $\begin{array}{c}\text { Total yield } \\
\left.\text { (tons hectare }^{-1}\right)\end{array}$ \\
\hline \multicolumn{4}{|c|}{ Average of Both Seasons } \\
\hline $\mathrm{I}_{5} \times \mathrm{T}_{1}$ & $4.848^{\mathrm{a}}$ & $6.442^{\mathrm{a}}$ & $29.679^{\mathrm{a}}$ \\
\hline $\mathrm{I}_{5} \times \mathrm{T}_{2}$ & $6.995^{\mathrm{a}}$ & $9.305^{\mathrm{a}}$ & $42.865^{\text {a }}$ \\
\hline $\mathrm{I}_{5} \times \mathrm{T}_{3}$ & $8.400^{\mathrm{a}}$ & $11.170^{\mathrm{a}}$ & $51.461^{\mathrm{a}}$ \\
\hline $\mathrm{I}_{5} \times \mathrm{T}_{4}$ & $6.605^{\mathrm{a}}$ & $8.788^{a}$ & $40.484^{\mathrm{a}}$ \\
\hline $\mathrm{I}_{5} \times \mathrm{T}_{5}$ & $5.862^{\mathrm{a}}$ & $7.788^{a}$ & $35.884^{\mathrm{a}}$ \\
\hline $\mathrm{I}_{5} \times \mathrm{T}_{6}$ & $7.306^{\mathrm{a}}$ & $9.709^{\mathrm{a}}$ & $44.731^{\text {a }}$ \\
\hline $\mathrm{I}_{5} \times \mathrm{T}_{7}$ & $7.799^{a}$ & $10.357^{\mathrm{a}}$ & $47.721^{\text {a }}$ \\
\hline $\mathrm{I}_{5} \times \mathrm{T}_{8}$ & $6.311^{\mathrm{a}}$ & $8.391^{\mathrm{a}}$ & $38.658^{\text {a }}$ \\
\hline $\mathrm{I}_{5} \times \mathrm{T}_{9}$ & $5.981^{\mathrm{a}}$ & $7.953^{\mathrm{a}}$ & $36.640^{\mathrm{a}}$ \\
\hline $\mathrm{I}_{5} \times \mathrm{T}_{10}$ & $7.138^{\mathrm{a}}$ & $9.476^{\mathrm{a}}$ & $43.662^{\mathrm{a}}$ \\
\hline $\mathrm{I}_{5} \times \mathrm{T}_{11}$ & $7.652^{\mathrm{a}}$ & $10.168^{a}$ & $46.848^{\mathrm{a}}$ \\
\hline $\mathrm{I}_{5} \times \mathrm{T}_{12}$ & $6.520^{\mathrm{a}}$ & $8.668^{\mathrm{a}}$ & $39.932^{\mathrm{a}}$ \\
\hline $\mathrm{I}_{5} \times \mathrm{T}_{13}$ & $7.017^{\mathrm{a}}$ & $9.312^{\mathrm{a}}$ & $42.912^{\mathrm{a}}$ \\
\hline $\mathrm{I}_{10} \times \mathrm{T}_{1}$ & $5.239^{a}$ & $9.250^{\mathrm{a}}$ & $25.983^{\mathrm{a}}$ \\
\hline $\mathrm{I}_{10} \times \mathrm{T}_{2}$ & $7.252^{\mathrm{a}}$ & $12.787^{\mathrm{a}}$ & $35.928^{\mathrm{a}}$ \\
\hline $\mathrm{I}_{10} \times \mathrm{T}_{3}$ & $7.078^{a}$ & $12.407^{\mathrm{a}}$ & $34.904^{\mathrm{a}}$ \\
\hline $\mathrm{I}_{10} \times \mathrm{T}_{4}$ & $6.197^{\mathrm{a}}$ & $10.869^{a}$ & $30.574^{\mathrm{a}}$ \\
\hline $\mathrm{I}_{10} \times \mathrm{T}_{5}$ & $6.176^{\mathrm{a}}$ & $10.877^{\mathrm{a}}$ & $30.568^{a}$ \\
\hline $\mathrm{I}_{10} \times \mathrm{T}_{6}$ & $6.476^{\mathrm{a}}$ & $11.383^{\mathrm{a}}$ & $32.005^{\mathrm{a}}$ \\
\hline $\mathrm{I}_{10} \times \mathrm{T}_{7}$ & $6.681^{\mathrm{a}}$ & $11.718^{\mathrm{a}}$ & $32.962^{\mathrm{a}}$ \\
\hline $\mathrm{I}_{10} \times \mathrm{T}_{8}$ & $6.469^{a}$ & $11.356^{\mathrm{a}}$ & $31.938^{\mathrm{a}}$ \\
\hline $\mathrm{I}_{10} \times \mathrm{T}_{9}$ & $5.960^{\mathrm{a}}$ & $10.463^{\mathrm{a}}$ & $29.426^{\mathrm{a}}$ \\
\hline $\mathrm{I}_{10} \times \mathrm{T}_{10}$ & $6.623^{a}$ & $11.626^{\mathrm{a}}$ & $32.699^{\mathrm{a}}$ \\
\hline $\mathrm{I}_{10} \times \mathrm{T}_{11}$ & $6.472^{a}$ & $11.434^{\mathrm{a}}$ & $32.114^{\mathrm{a}}$ \\
\hline $\mathrm{I}_{10} \times \mathrm{T}_{12}$ & $6.567^{\mathrm{a}}$ & $11.540^{\mathrm{a}}$ & $32.449^{\mathrm{a}}$ \\
\hline $\mathrm{I}_{10} \times \mathrm{T}_{13}$ & $6.514^{\mathrm{a}}$ & $11.400^{\mathrm{a}}$ & $32.082^{\mathrm{a}}$ \\
\hline L.S.D $(p \leq 0.05)$ & n.s & n.s & n.s \\
\hline
\end{tabular}

Table 8. The effect of seasons on WUE, IWUE and total yield

\begin{tabular}{c|c|c|c}
\hline Seasons & WUE $\left(\mathbf{k g ~ m}^{\mathbf{- 3}}\right)$ & IWUE $\left(\mathbf{k g ~ m}^{\mathbf{- 3}}\right)$ & $\begin{array}{c}\text { Total yield } \\
\left.\text { tons hectare }^{-\mathbf{1}}\right)\end{array}$ \\
\hline First Season 2017 & $6.627^{\mathrm{a}}$ & $10.070^{\mathrm{a}}$ & $36.311^{\mathrm{a}}$ \\
Second Season 2018 & $6.614^{\mathrm{a}}$ & $10.287^{\mathrm{a}}$ & $37.159^{\mathrm{a}}$ \\
L.S.D $(\mathbf{p} \leq \mathbf{0 . 0 5})$ & $\mathbf{n . S}$ & $\mathbf{n . s}$ & $\mathbf{n . s}$ \\
\hline
\end{tabular}

\section{Discussion}

These result accused the role of the interaction of irrigation intervals and different treatments, increased wetted soil volume inside root zone, and this mean increasing in water volume which was stored in root zone. The differences on the total yield can be explained by the influence of the biotic and abiotic application on WUE and IWUE which in return maximize the total yield.

Results of WUE indicated the importance of the treatments to achieve good yield and better utilization of water, which can be attributed to the role of Mycorrhizal inoculation in improving crop resistance to water stress and other stresses. In the first season 2017, no significant difference was observed in term of WUE and this may be due to the distribution and the amount of rainfall in this season was enough to bear plants water requirement in the 10 days irrigation intervals.

Thus, increase of phosphorus uptake by mycorrhizae considering the role of phosphorus in molecular structures such as nucleic acids, stomatal conductance, and photosynthesis increases the tolerance of plants against water stress. 
Biofertilization has emerged in order to minimize environmental impacts and take advantage of the resources available in the field.

Therefore, it can be concluded that the biotic application with good crop management can achieve good productivity and high WUE in Iraqi Kurdistan region conditions.

The treatment of mycorrhizae inoculation for the highest values in WUE and IWUE may be due to its high ability to produce the glomalin compound, which binds the soil minutes to each other and to the aggregation of aggregates, as well as the role played by the mycelium hypha in mass soil actions and increase its stability. Fokom et al. (2012) indicates that there are positive correlations of correlations between organic matter and chlorine associated with Glomalin Related Soil Protein (GRSP). Peng et al. (2013) noted that the soil fertilized with mycorrhizae increases the stability of its aggregates as a result of the action of the mycorrhizae hypha and the result of its production of glomalin, a watery and insoluble molybdenum protein compound that contributes to the formation and increase stability of the soil complexes where it is released to the and reduce their hydration because it is a glue-absorbing composite. Martin et al. (2012) and $\mathrm{Wu}$ et al. (2013) reported that organic matter also plays an important role in improving the properties of physical, chemical and biological soil. Microorganisms are fertilized with food and increase their activity, which positively affects the increase in the activity of the Mycorrhizae (Ochl et al., 2003). All of these factors improve soil properties and increase their water retention.

The Glycyrrhiza glabra extract contains some acids, monosaccharide's, various vitamins (E, C and B), folic acid and various elements such as calcium, iron, silicon, aluminum, magnesium, sulfur, potassium, zinc and phosphorus, which play an important role in growth (Vispute and Khopade, 2011). Glycyrrhiza glabra extract also contains mevalonic acid, which enters the synthesis of gibberellins (Moses et al., 2002).

Potassium is also associated with many other important phylogenetic functions, including activation of enzymes, regulation of opening and closing of stents, as well as its important role in the synthesis of ATP, where the electrostatic charge in the ATP production sites is closely related to the $\mathrm{K}^{+}$(Prajapati and Modi, 2012) and sugars (Van Brunt and Sultenfnss, 1998), water and nutrient transport (Thomas and Thomas, 2009) and protein synthesis and starch (Patil, 2011).

\section{Conclusion}

The irrigation intervals had great influence on WUE and the total yield of potato, the 5 days intervals overcome the 10 days intervals at 2017 and 2018 season's and the average of both seasons with exception of the character WUE of at the first season. Mycorrhizal inoculation maximize the WUE, IWUE and the total yield at the first season 2017 and the average of both seasons, this indicated that the Mycorrhizal inoculation will improve the WUE, IWUE and the total yield depending on the seasonal condition. At the second season the application of $\left(2.5 \mathrm{~g} \mathrm{~L}^{-1}\right) \mathrm{KCl}$ with $\left(6 \mathrm{~g} \mathrm{~L}^{-1}\right)$ Glycyrrhiza glabra extract gave the highest value for the studied characters the rainfall quantity in this season was more in April and May 2018 comparing with the same months in 2017 which leads to increase the role of this combination. 


\section{REFERENCES}

[1] Al-Rawi, K. M., Khalaf-Allah, A. M. (1980): Design and analysis of agricultural experiments. - El Mousel Univ. Iraq 19: 487.

[2] Ati, A. S., Shihab, R. M., Aziz, S. A., Ahmed, F. H. (2010): Production and water use of potato under regulated deficit irrigation treatments. - Annals of Agricultural Science (Cairo) 55(1): 123-128.

[3] Ati, A., Nafaou, S. M. (2012): Effect of potassium fertilization on growth, yield and water use efficiency of irrigated potato. - Misr Journal Agricultural Engineering 29(2): 735744.

[4] Ati, A. S., Iyada, A. D., Najim, S. M. (2012): Water use efficiency of potato (Solanum tuberosum L.) under different irrigation methods and potassium fertilizer rates. - Annals of Agricultural Sciences 57(2): 99-103.

[5] Ati, A. S., Al-Sahaf, F., Wally, D. H., Thamer, T. E. (2013): Effects of Potassium Humate Fertilizers and Irrigation Rate on Potato Yield and Consumptive Use under Drip Irrigation Method. - Journal of Agricultural Science and Technology: 803-810.

[6] Beder, O. M. A. (2010): Recent Irrigation scheduling techniques for improving water use in landscaping. - Fourteenth International Water Technology Conference, IWTC 14 2010, Cairo, Egypt.

[7] Birhane, E., Sterck, F. J., Fetene, M., Bongers, F., Kuyper, T. W. (2012): Arbuscular mycorrhizal fungi enhance photosynthesis, water use efficiency, and growth of frankincense seedlings under pulsed water availability conditions. - Oecologia 169(4): 895-904.

[8] Doorenbos, J. (1977): Crop Water Requirements. - Irrigation and Drainage paper 24: 144.

[9] Duc, N. H., Mayer, Z., Pék, Z., Helyes, L., Posta, K. (2017): Combined inoculation of arbuscular mycorrhizal fungi, Pseudomonas fluorescens and Trichoderma spp. for enhancing defense enzymes and yield of three pepper cultivars. - Applied Ecology and Environmental Research 15(3): 1815-1829.

[10] Egilla, J. N., Davies, F. T., Boutton, T. W. (2005): Drought stress influences leaf water content, photosynthesis, and water-use efficiency of Hibiscus rosa-sinensis at three potassium concentrations. - Photosynthetica 43(1): 135-140.

[11] Erdem, T., Erdem, Y., Orta, H., Okursoy, H. (2006): Water-yield relationships of potato under different irrigation methods and regimens. - Scientia Agricola 63(3): 226-231.

[12] Esho, T., Enzlin, P., Van Wolputte, S., Temmerman, M. (2010): Female Genital Cutting and Sexual Functioning: in Search of an Alternate Theoretical Model. - African Identities 8(3): 221-234.

[13] FAOSTAT (2019): Food and Agricultural Organization of the United Nations, Statistics, Rome, Italy. - http://www.fao.org/faostat/en/\#data/QC.

[14] Fokom, R., Adamou, S., Teugwa, M. C., Boyogueno, A. B., Nana, W. L., Ngonkeu, M. E. L., Zollo, P. A. (2012): Glomalin related soil protein, carbon, nitrogen and soil aggregate stability as affected by land use variation in the humid forest zone of south Cameroon. - Soil and Tillage Research 120: 69-75.

[15] Goussous, S. J., Mohammad, M. J. (2009): Comparative effect of two arbuscular mycorrhizae and $\mathrm{N}$ and $\mathrm{P}$ fertilizers on growth and nutrient uptake of onions. International Journal of Agriculture and Biology 11(4): 463-467.

[16] Grewal, J. S., Sharma, R. C., Saini, S. S. (1992): Agrotechniques for intensive potato cultivation in India. - Indian Council of Agricultural Research; New Delhi.

[17] Hassan, A. A., Sarkar, A. A., Ali, M. H., Karim, N. N. (2002): Effect of deficit irrigation at different growth stages on the yield of potato. - Pakistan Journal of Biological Sciences 5(2): 128-134. 
[18] Howell, T. A., Cuenca, R. H., Solomon, K. H. (1990): Crop yield response. - In: Hoffman, G. J., Howell, T. A., Solomon, K. H. (eds.) Management of Farm Irrigation Systems. Chapter 5, pp. 93-122. ASAE Monograph, ASAE, St. Joseph, Michigan.

[19] Kirda, C. (2002): Deficit irrigation scheduling based on plant growth stages showing water stress tolerance. - http://www.fao.org/library/library-home/en/.

[20] Kiziloglu, F. M., Sahin, U., Tune, T., Diler, S. (2006): The Effect of Deficit Irrigation on Potato Evapotranspiration and Tuber Yield under Cool Season and Semiarid Climatic Conditions. - Journal of Agronomy 5(2): 284-288.

[21] Latef, A. A. H. A., Miransari, M. (2014): The role of arbuscular mycorrhizal fungi in alleviation of salt stress. - Use of microbes for the alleviation of soil stresses, pp. 23-38, Springer, New York, NY.

[22] Lazim, Z. S., Sulaiman, S. M. (2012): Effect of gibberillic and liquorice extract on seed germination of black seed (Nigella sativa L.). - Iraq.J.Agric.Res. 17(1): 105-113.

[23] Martin, S. L., Mooney, S. J., Dickinson, M. J., West, H. M. (2012): Soil structural responses to alterations in soil micro biota induced by the dilution method and mycorrhizal fungal inoculation. - Pedobiologia 55(5): 271-281.

[24] Moses, T. N., AbdulJabbar, W. A., Elwy, A. N. (2002): Study of some local licorice root powder components (Glycyrrihiza glabra L.). - Iraq. J. of Agric. Sci. 33(4): 30-38.

[25] Nagaz, K., Masmoudi, M. M., Mechlia, N. B. (2007): Soil salinity and yield of dripirrigated potato under different irrigation regimes with saline water in arid conditions of Southern Tunisia. - Journal of agronomy 6(2): 324.

[26] Najmaddin, P. M., Whelan, M. J., Balzter, H. (2017): Estimating daily reference evapotranspiration in a semi-arid region using remote sensing data. - Remote Sensing 9(8): 779.

[27] Oehl, F., Sieverding, E., Ineichen, K., Mäder, P., Boller, T., Wiemken, A. (2003): Impact of land use intensity on the species diversity of arbuscular mycorrhizal fungi in agro ecosystems of Central Europe. - Applied Environmental Microbiology 69(5): 2816-2824.

[28] Patil, R. B. (2011): Role of potassium humate on growth and yield of soybean and black gram. - International Journal of Pharma and Biosciences 2(1): 242-246.

[29] Peng, S., Guo, T., Liu, G. (2013): The effects of arbuscular mycorrhizal hyphal networks on soil aggregations of purple soil in southwest China. - Soil Biology and Biochemistry 57: 411-417.

[30] Prajapati, K., Modi, H. A. (2012): The importance of potassium in plant growth-a review. - Indian Journal of Plant Sciences 1(02-03): 177-186.

[31] Rashidi, M., Gholami, M. (2008): Review of crop water productivity values for tomato, potato, melon, watermelon and cantaloupe in Iran. - Int. J. Agric. Biol. 10: 432-436.

[32] Reddy, M. J., Nagesh Kumar, D. (2007): Multi-objective particle swarm optimization for generating optimal trade-offs in reservoir operation. - Hydrological Processes: An International Journal 21(21): 2897-2909.

[33] Sabry, G. H., Rizk-Alla, M. S., Abd El-Wahab, M. A. (2009): Influence of effective micro-organisms, seaweed extract and amino acids application on growth, yield and bunch quality of Red globe grapevines. - J. Agric. Sci. Mansoura Univ. 34(6): 59015921.

[34] Shock, C. C., Zalewski, J. C., Stieber, T. D., Burnett, D. S. (1992): Impact of early-season water deficits on Russet Burbank plant development, tuber yield and quality. - American Potato Journal 69(12): 793-803.

[35] Shock, C. C. (2004): Efficient irrigation scheduling. - Malheur Experiment Station, Oregon State University, Oregon, USA.

[36] Thomas, T. C., Thomas, A. C. (2009): Vital role of potassium in the osmotic mechanism of stomata aperture modulation and its link with potassium deficiency. - Plant Signal Behaviour 4(3): 240-243.

[37] Thornton, M. K. (2002): Effects of heat and water stress on the physiology of potatoes. Idaho Potato Conference, Idaho. 
[38] Van Brunt, J. M., Sultenfuss, J. H. (1998): Better crops with plant food. - Potassium: Functions of potassium 82(3): 4-5.

[39] Van Loon, C. D. (1981): The effect of water stress on potato growth, development, and yield. - American Potato Journal 58(1): 51-69.

[40] Vispute, S., Khopade, A. (2011): Glycyrrhiza glabra Linn.-"Klitaka": a review. - Int J Pharma Bio Sci. 2(3): 42-51.

[41] Wang, C., Deng, P., Chen, L., Wang, X., Ma, H., Hu, W., He, G. (2013): A wheat WRKY transcription factor TaWRKY10 confers tolerance to multiple abiotic stresses in transgenic tobacco. - PloS one 8(6): e65120.

[42] Wright, J. L., Stark, J. C. (1990): Potato. - In: Stewart, B. A., Nielson, D. R. (eds.) Irrigation of Agricultural Crops. American Society of Agronomy, Crop Science Society of America, Soil Science Society of America, Madison, USA. pp: 859-889.

[43] Wu, Q. S., Srivastava, A. K., Zou, Y. N. (2013): AMF-induced tolerance to drought stress in citrus: A review. - Scientia Horticulturae 164: 77-87.

[44] Yuan, B. Z., Nishiyama, S., Kang, Y. (2003): Effects of different irrigation regimes on the growth and yield of drip-irrigated potato. - Agricultural water management 63(3): 153-167.

\section{APPENDICES}

Appendix 1. Mean squares of the analysis of variance for the characters WUE, IWUE and total yield

\begin{tabular}{|c|c|c|c|c|}
\hline S.O.V & d.f & $\begin{array}{c}\text { WUE } \\
\left(\mathrm{kg} \mathrm{m}^{-3}\right)\end{array}$ & $\begin{array}{c}\text { IWUE } \\
\left(\mathrm{kg} \mathrm{m}^{-3}\right)\end{array}$ & $\begin{array}{c}\text { Total yield } \\
\left.\text { (tons hectare }^{-1}\right)\end{array}$ \\
\hline \multicolumn{5}{|c|}{ First Season } \\
\hline Blocks & 2 & 3.244 & 8.034 & 89.522 \\
\hline Irrigation Interval (A) & 1 & $0.891^{\text {n.s }}$ & $128.159 *$ & $1315.348 *$ \\
\hline Error (a) & 2 & 0.369 & 1.500 & 4.263 \\
\hline Treatments (B) & 12 & $3.644 *$ & $8.135 *$ & $114.325 *$ \\
\hline$(\mathrm{A} \times \mathrm{B})$ & 12 & $0.747^{\text {n.s }}$ & $1.553^{\mathrm{n} . \mathrm{s}}$ & $28.440^{\text {n.s }}$ \\
\hline Error (b) & 48 & 0.863 & 2.030 & 26.185 \\
\hline \multicolumn{5}{|c|}{ Second Season } \\
\hline Blocks & 2 & 0.350 & 1.102 & 9.826 \\
\hline Irrigation Interval (A) & 1 & $17.269 *$ & $77.034 *$ & $2558.859 *$ \\
\hline Error (a) & 2 & 0.609 & 1.726 & 17.857 \\
\hline Treatments (B) & 12 & $2.813^{*}$ & $6.018 *$ & $94.861 *$ \\
\hline $\mathrm{A} \times \mathrm{B}$ & 12 & $1.678^{\text {n.s }}$ & $3.285^{\text {n.s }}$ & $59.723^{\text {n.s }}$ \\
\hline Error (b) & 48 & 1.173 & 2.528 & 39.745 \\
\hline
\end{tabular}

Appendix 2. Combined analysis of variance for the characters WUE, IWUE and total yield for both seasons

\begin{tabular}{c|c|c|c|c}
\hline S.O.V & d.f & $\begin{array}{c}\text { WUE } \\
\left(\mathbf{k g ~ m}^{-\mathbf{3}}\right)\end{array}$ & $\begin{array}{c}\text { IWUE } \\
\left(\mathbf{k g ~ m}^{-\mathbf{3}}\right)\end{array}$ & $\begin{array}{c}\text { Total yield } \\
(\text { tons hectare }\end{array}$ \\
\hline Seasons (S) & 1 & $0.006^{\mathbf{n} . \mathbf{s}}$ & $27.995^{\mathbf{n . s}}$ \\
Error (a) & $\mathbf{4}$ & $\mathbf{1 . 7 9 7}$ & $1.842^{\mathbf{n . s}}$ & $\mathbf{4 9 . 6 7 4}$ \\
Irrigation Interval (A) & 1 & $5.157^{*}$ & $\mathbf{4 . 5 6 8}$ & $3771.713^{*}$ \\
A $\times$ S & 1 & 13.002 & $201.958^{*}$ & 102.494 \\
Error (b) & $\mathbf{4}$ & $\mathbf{0 . 4 8 9}$ & 3.235 & $\mathbf{1 1 . 0 6 0}$ \\
Treatments (B) & 12 & $5.623^{*}$ & $12.095^{*}$ & $183.647^{*}$ \\
B $\times$ S & 12 & 0.834 & 2.058 & 25.540 \\
A $\times$ B & 12 & $1.096^{\mathbf{n . s}}$ & $1.668^{\mathbf{n . s}}$ & $48.166^{\mathbf{n . s}}$ \\
A $\times$ B $\times$ S & 12 & 1.329 & 3.170 & 39.998 \\
Error (c) & $\mathbf{9 6}$ & $\mathbf{1 . 0 1 8}$ & $\mathbf{2 . 2 7 9}$ & $\mathbf{2 7 . 9 9 5}$ \\
\hline
\end{tabular}

